\title{
THE NEW PEOPLE IN THE UKRAINIAN LITERATURE OF THE 1920S-1930S
}

\section{Romanenko O. V.}

\section{INTRODUCTION}

The literary process of the 1920s-1930s in Ukraine is a period of change of ideas about a person and ways of depicting a person in works of art. Literary innovations of the 1920's. reflect the destruction of the old and at the same time the formation of a new system of imagery at all levels of works of art: from a single word-image to a composition.

The study of this phenomenon in Ukrainian literary studies took place in two periods. The first one dates from the late 1980s -to the mid-1990s. It has been started by "The Right to a Grateful Memory" discassion of 1988 published on the pages of the newspaper "Literary Ukraine". It was the first professional discourse about the literary process of the 1920s and 1930s and about returning to studying repressed writer's works. This discussion enabled the researchers to prepare dissertations on the works of Mykola Khvylovy, Valeryan Pidmogilny, Hryhoriy Kosynka, Mikhail Semenko, Mike Yogansen, Yevgeny Pluzhnik and other Ukrainian writers, repressed by the Soviet authorities ${ }^{1}$. These were academic studies that made it possible to return forgotten names to the Ukrainian literary canon and restore the idea of the holistic development of the literary process of the 1920s and 1930s inwide scientific circles and in school textbooks. An interim result of this phase was also the system series "Shootout Renaissance""of the Smoloskip publishing house. These are academic publications that feature the works of authors of the 1920s and 1930s, as well as literary-critical material about their creativity, epistolary, excerpts from memoirs, and powerful scientific commentary.

${ }^{1}$ See, for example: Філатова О. С. Український роман 20 - 30-х років ХХ століття: типологія авторської свідомості. К.: Київ. нац. ун-т ім. Т. Шевченка. Миколаїв : Іліон, 2010. 484 с.; Кавун Л. І. “М'ятежні” романтики вітаїзму: проза Вапліте. Черкаси: Брама-Україна, 2006. 328 с.; Хархун В. П. Соцреалістичний канон в українській літературі: генеза, розвиток, модифікації. Ніжин: Гідромакс, 2009. 508 с. та ін.

${ }^{2}$ See, for example: Хвильовий М. Г. Вибрані твори. Упоряд. Ростислав Мельників. К.: Смолоскип, 2011. 1035 с. 
Ubsequently, on the initiative of "Tempora"publishing house and Yarina Tsymbal, the "Our 20s" project was created ${ }^{3}$. Its purpose is to popularize the writers of the 1920s and 1930s. Nowadays, these are popular scientific articles by Yaryna Tsymbal on the "Litakcent" portal and in the "Ukrainian Week" magazine, a series of "Our 20's" books, and numerous discussions at literary and book festivals. Such a project intensified attention to this period, gave the opportunity to draw attention to the little-studied, but still topical issues. These include echoing ideas about the changes of human, the emergence of a new human, a radical change in ideas about how to portray human in a piece of art. The beginning of the 20th century in Ukraine drew attention to fundamental questions: what is human? How willpeople be looking like in the future? How will the personality of humankind change or is it changing now? The answers to these questions were often controversial. Yes, futurism welcomed the emergence of a new person, impressionism tried to describe the nuances of itstemper and experiences, realism - to record real events and changes in person's psychology.

In the events of the early 20th century, Ukrainian writers saw the process of "creating a new person", "remaking and re-equipping the entire old world, all psycho-ideological and psychophysical features and qualities of man and society" ${ }^{\prime 5}$ while critics were discussing the emergence of a new type of person -the social one. Critics have been very active in discussing the relationship between social change and the emergence of a new kind of pearson. Yes, Yakov Savchenko wrote: "Human ... is aware of itself, first of all, as of a certain social energy and as a certain social active will ..."6, Boris Kovalenko defended the thesis of "class pearson", "directly related to the process of class struggle", "a monolithic type, a type of monolithic revolutionist and a monolithic counter-revolutionist"7.

"AliveHuman" or "Class Human"- this contradiction of literary debates in Ukraine in the 1920s and 1930s is still relevant forliterary historians. The intersection of ideas, methodological approaches, literary practices and theories - this was the period of the 1920s and 1930s in Ukraine. The sociocultural phenomenon of this time and the aesthetic changes in literary practices, style, genres are an interesting example of the early 20th century

\footnotetext{
${ }^{3}$ http://litakcent.com/category/20-ti-live/

${ }^{4}$ Івченко М. Записники. 1915-1933 роки.Відділ рукописів ін-ту лі-тератури ім. Т.Г. Шевченка. Ф.109. № 89-93.

${ }^{5}$ Репресоване "Відродження". Упоряд. О. І. Сидоренко, Д. В. Табачник. К.: Україна, 1993. С. 4.

${ }^{6}$ Ibid.

${ }^{7}$ Коваленко Б. Пролетарські письменники. Х.-К. Державне вид-во “Література і мистецтво", 1931. С. 187.
} 
literary process development. And this research is only small part of the overall panoramic vision'sreflection of Ukrainian literature of that time. In the literary process of that time, three conceptual ideas about the human vision in culture and literature were formed: a social / commonpearson, aFaustian type ofpearson, a ironically depicted type of pearson. They have been variously described in fiction and have been ambiguously criticized. This is evidenced, in particular, by the existence of three types of characters in the literature: a mythological hero,aFaustian type ofpearson, a ironically depicted type of pearson.

\section{Mythological hero}

Throng, crowd, people as part of a large collective those concepts are ones of the biggest trends of that time. This period in Ukrainian history, culture and literature, on the one hand, is the time of forthcoming to European trends, and on the other hand, it isthe period of active standardization of culture. Creation of the one-dimensional model of culture on the basis of so-called social realistic practice. Moreover, Elena Levchenko analyzes the text of Soviet culture as a whole semiotic system and writes that in the first half of the 20th century in Ukraine and throughout the Soviet Union there was a "rapid transcoding of the culture text in the system of mass audience expectations... the downfall of the actual artistic culture system, under simplified mass audience codes ... and the aforementioned desire for the "low" culture to take the place over the"high" one, adapting its forms" important role in these processes. Critic Boris Yakubsky put forward a demand for writers - “... while creating, we must look not for what sets us apart from the crowd, like individualistsused to do, but to the contrary, look for what associates us with the crowd,what we have in common with it, how we feel it inside of ourselves"

This has brought a special type of character to the forefront of Ukrainian literature - a person of certain social class, mostly - a worker, depicted on the stereotyped principlesof personality reproduction. Critic Vladimir Koryak called such type of a character a "monolithic Bolshevik who subordinates his individual life to social interests" ${ }^{\prime \prime}$. In such type of a character, the criticsprefer to see the following characteristics:

8 Левченко О. Г. Текст культури в пошуках автора: Масова свідомість і художня культура у контексті радянської культури (за матеріалами театру і кіно) / Держ. центр театр. мистец. ім. Леся Курбаса. К., 2006. С. 158.

${ }^{9}$ Якубський Б. Життя молоде (Спроба літературної характеристики “київських плужан”). Червоний шлях. 1925. № 9. С. 160.

${ }^{10}$ Коряк В. В боях: Статті і виступи 1925-1930.Х.: Література і мистецтво, 1933. C. 208. 
- Typicality (Ivan Mykytenko emphasized that "the poor middling proletarian must be presented so that he remains an artistic type even when there will be neither middlingnor poor" ${ }^{\prime 11}$ );

- social expediency (Michael Dolenga wrote that "the realism of the proletarian describes a modern transitional age sociographically, based on its sociological study"12);

- the ideological evolution of the hero (as noted by V. SikhnoKhomenko, the task of literature is "to create typical characters in the process of their composition, showing their psychological, ideological evolution" ${ }^{\prime 13}$ ).

And such characters were in Ukrainian literature. For example, Ivan Mykytenko creates several dramas dedicated to this type of character. These are the dramas "Dictatorship" (1929), "Shine On Us, Dawns" (1930; another title of this play -"Shots"), "The Case of Honor" (1931), "Our Country Girl" (1933) and others. Mostly, these are dramas that combine realism and elements of propaganda, melodrama and heroic pathos. Yes, the main character of the play "Girls of our country"- Masha Shapiga - repeatedly talks about a new person, a person of the future. As this pearson, Masha Shapiga imaginesonly the Bolshevik type of pearson, who abandons the old world: "I want to talk about one battle in our construction site. Battle for a man, for a friend, for a Komsomol member, he who had lost his dignity, began to deceive his comrades, began to advertise himself in the newspapers. For the hostile woman, he gave everything he had as a Komsomolmember..." ${ }^{14}$ Ivan Mykytenko gives all his characters a clear social characteristic: the Bolshevik, the peasant, the worker, the kulak, the student and others. In Ivan Mykytenko's dramas there are a lot of pathetic mass scenes, a lot of the same characters, a sharp social conflict between the so-called old and new world. Such works were modeled and distributed to readers in the Ukrainian literature of the character - mythologically hero. He is endowed with impeccable character traits, positive, belongs to a certain social stratum, never reflects. This is the type of revolutionary that changes the world.

This type of character became central to the Soviet Union's culture and literature system. His traits are focused on the ideas and style of mass culture and literature. In the early 20th century, a new myth was formed in

${ }^{11}$ Микитенко І. Пролетарська література за доби реконструкції (Доповідь на другому з’їзді ВУСП (звіт секрет.).Гарт. 1929.№ 9. С. 129.

12 Доленго М. Післяжовтнева українська. Червоний шлях. 1927. № 11. С. 155.

${ }^{13}$ Сихно-Хоменко І. Пролетарська література. Життя і револючія. 1929. № 12. C. 48 .

${ }^{14}$ Микитенко І. К. Твори: в 4 т. Т. 3. П'єси. Упоряд. О. І. Микитенко. К.: Дніпро, 1983. C. 326. 
Ukrainian literature about the so-called new society, embodied in the practices of the literature of socialist realism. The literature of proletarian (socialist) realism is a unique creation of the socio-ideological authority's order. Such literature combines elements of utilitarianism and high pathos, its subjects should conform to clearly defined ideological schemes. In works of socialist realistic literature, the author clearly adheres to ideologically marked meanings, images, symbols, as they exert the expected effect on the reader. Such literature is based on the principles of pathos and rhetorical poetics, optimism. The type of narrative and genre that the author chooses in socialist realism are based on the principles of repetition, fixed schemes, which is characteristic of the poetics of mass literature.

The proletarian character,the person with a clearly described social trait, is central to the system of so-called socialist literature. Such a character is central to the new mythological paradigm of public consciousness and central to the mass media of this period. Forming a new system of semiotic codes, Soviet society is in dire need of new myths, new plots to replace the old, bourgeois plots, myths, and create a coherent narrative space for the new and high, and for the mass culture. This process is very important for any cultural and aesthetic revolution, because "by creating story texts, one has learned to differentiate stories in life and thus interpret this life for himself ${ }^{\prime 15}$. Here comes one of the most important artistic and social conflicts in the Ukrainian realities of the 1920s and 1930s: among the total mythological subjects of the new revolutionary update of reality, the pathetic depiction of the mythological titanic character inspired by the ideas of Bolshevism, there was virtually no place for a divisive person dramatic existential pursuits. The realm of the dramatic shifted from existential personal conflicts and dramas to the plane of another: in a society initially formed as anti-bourgeois, anti-old, dramatization concerned the confrontation of "ours \& foreign", "the Bolshevik \& Belogvardiysky", "soviet \& bourgeois", "soviet \& nationalistic". This semantic code was extremely powerful, especially in the sphere of mass consciousness and mass literature, because it was based on the juxtaposition of "ours \& foreign" (space, world, etc.), known from archaic folklore texts.

\section{The Faustian type of character}

Another type of character in Ukrainian literature of the 1920s and 1930s is also interesting. It is reproduced in the prose of Mykola Khvylovy: "I (Romance)", "Lilyuli", "Sanatorium Zone" and others. Mykola Khvylovy's characters are experiencing existential crises, disappointments in

\footnotetext{
15 Лотман Ю. М. Семиосфера. СПб: “Искусство-СПБ”, 2010. С. 297.
} 
the revolution, daily encounter with bourgeoisie, see that life is not as sublime and beautiful as they imagined it to be. Almost all of Mykola Khvylovy's prose characters are depicted in times of crisis. For example, the main character of the story "Sanatorium Zone" is disappointed in the confined space of the sanatorium outside the city. In his mind reality is combined with phantom images. At some point, Anarch decides that "there is no longer any thing that is on the other side of reality ... that it is, at last, so easy, without any obstacles, to fall into this unknown land"16. Along with the phantom images in Anarch consciousness there are real ones. He believes in revolutionary change, in the emergence of a new person and a new, better world. In the works of Nikolai Khvylovy this world is a mountainous commune, blue lakes of a distant mountainous commune. This is a symbolic future that the characters of Nikolay Khvylovy's prose seek. The split of consciousness is the most important feature of Mykola Khvylovy's characters. Such a character can be called a human. The human with tragic worldview, Faustian character. This definition is not accidental. Because Mykola Khvylovy writes about the appearance of such a typical person in his pamphlets "Come on?", "Ukraine or Little Russia?", "Thoughts against the Current" and others. the writer argued that the time was coming for "the rebirth of a strong and whole pearson, the revival of a new type of brave conquistadors, who are also saddened by European society" ${ }^{\prime 1}$. Such a person constantly doubts, seeks true feelings, seeks and does not find harmony in the world. Mykola Khvylovy calls such a person - "a brilliant restless citizen"18, "Faustian type". Mykola Khvylovy describes a person who lives in an era of revolutionary change as a person with split consciousness. As Mykola Khvylovy wrote, "When you are a revolutionary, you will split your "I" more than once". His characters are experiencing psychological breakdown, a tragic search for their "I"19. These are lonely personalities, their illusions of revolutionary renewal of the world destroyed. They sought to live in a new world, but found themselves among the bourgeoisie and primitivism. Such a contrast between reality and dream is particularly interestingly depicted in the short story of Mykola Khvylovy's "Lilyuli". This piece is a genre modification of Christmas short story and realistic short story. The main character midget Alyosha creates a New Year's Day agitation play to greet the new authorities and new times, but does not see joy in the new world. On the contrary, the short story depicts an ironic and

\footnotetext{
${ }^{16}$ Хвильовий М. Твори в 2-х т. Т.1-2. К.: Дніпро, 1990. С. 480.

${ }^{17}$ Ibid., c. 64 .

${ }^{18}$ Ibid., c. 621 .

${ }^{19}$ Ibid., c. 421.
} 
tragic situation, because in the new era, in the new time, there is no place for any of the characters. All of them are unhappy, confused.

Mykola Khvylovy's characters are people in an era of revolutionary change. These are the personalities who embody the "duality of man", because by Mikhail Khvylovy's definition: "When you are a revolutionary you will split your"I"more than once"20. Mykola Khvylovy portrays how a long and thoughtless passion for the romantic ideals of the revolution and the future had transformed people. The differences between revolutionary ideals and primitive reality create a conflict in the minds of the characters. They even begin to doubt that they really exist. In fact, Chloe (the character of the story "Sanatorium Zone") asks: "what am I: reality or phantom?"21. Mykola Khvylovy's characters portray real world perception and phantom perceptions of the world. These are people with a split consciousness, split between the real and the surreal, the rational and the emotional.

In order to tell the story of such a character, Nikolai Khvylovy chooses the short story genre. In a concise story he manages to convey the tragedy of the situation and the dramatic emotions of the character. Mostly at the center of the story is one event and a lot of character thoughts. Mykola Khvylovy describes in detail their thoughts, experiences, not consistently, but in passages. This makes it possible to recreate the inner world of the character as split, forked, and dramatic. Anrah (the short story "Sanatorium Zone"), the midget Alyosha (the short story "Lulili"), the character of the short story" I (Romance)"- are lonely personalities who are on the sidelines of the new era. Such a lonely person feels how quickly and dramatically historical time changes. But at the same time, they feel unable to meet the demands of time. To recreate such a conflict, Nikolai Khvylovy uses the techniques of collage letter. The main atmosphere focus is not concentrated on the consistent reproduction of the events and characters actions, but on fixing the chaotic movement of thoughts, emotions, impressions, experiences of the characters. It creates a mosaic composition and a tense psycho-emotional story line in the short story of Mykola Khvylovy. In order to depict a Faustian character, the writer chooses the following artistic means: poetic associations, metaphors, symbol images, impressionistic colors - to reproduce emotions and experiences. Interestingly, he makes the descriptions of the character's appearance as individual as possible with only one noticeable detail. For example, the midget Alyosha from the novel "Lilyuli"has eyes that "looked at Calvary", similary, Vadim from the short story"Blue Novemberis" described as: "a dot" as if emphasizing that Vadim's life was reduced to a dot.

\footnotetext{
${ }^{20}$ Хвильовий М. Твори в 2-х т. Т. 1-2. К.: Дніпро, 1990. С. 421.

${ }^{21}$ Ibid., c. 472
} 
Faustic-type characters are placed in a difficult choice of life, they are on the verge of emotional tension, they hesitate to follow an ideology and possibly commit crimes, or to pursue humanity and not commit crimes. Mykola Khvylovy is trying out his character and putting him in a difficult choice between rational and emotional, between real and phantom, between ideology and humanity.

\section{The laughing pearson}

A particular type of character in Ukrainian literature of the 1920s and 1930s is an ironic or satirical character. Among the humor writers of this period the most interesting is Ostap Wyshya. His works are an example of interesting phenomenon in Ukrainian literature of the 1920s and 1930s a combination of an ideological component and literary play. Ostap Wishny's readership is unique: it could be an intellectual reader struck by the author's preschool ironic rich humor, or a mass reader unprepared, often illiterate. Ostap Wyshya's creativity ${ }^{22}$ is an example of addressing works to two types of audiences - the intellectual and the mass. The author addresses his stories to two polar audiences, his works had found active response in both types ofaudiences, they became popular, though interpreted differently. Ostap Wyshya's interpretive humorous models are multilevel: mass audience would have dedicated themselves to his characters, whilethe intellectual ones would have recognizedthe phenomensthat Ostap Wyshyawas criticizing.

Such different types of perception around the "smiles" of Ostap Wyshyacreated a polyphonic interpretive sphere, which was combining the common and the special, the irony and the drama, the stereotyped images and thedeep metaphors. The same works are aimed bymass reader andby refined intellectual reader. Ostap Wyshya'sworks had succeeded in expanding the circle of his admirers and supporters for the first time in Ukrainian literature, due to his appeal to two audiences at the same time. The "smiles"were a holistic semiotic space, which combines the features of high and mass literature. Ostap Wyshya's"smiles" Bwere based on the principles of literary play, they were a hybrid form of avant-garde practices and popular mass forms of creativity, in particular, the traditions of anecdote, interlude, and nativity scene. Ostap Wyshya takes interest in the true facts fromthe avant-garde practices. The writer actually writes his works as reports from the scene. They are very realistic and are accurately reflecting the real life events of peasants, workers or residents of the

${ }^{22}$ Вишня Остап. Твори в 5 т. Т. 2. Усмішки, фейлетони, гуморески. К.: Дніпро, 1974. 
1920s-1930s. Along with avant-garde practices, Ostap Wyshya uses a genre model of anecdote, interludes with which the general public is familiar. So there is a special genre in the writer's work - a "smile". It combines irony and satire, realism and carnivalism.

In Ostap Wyshya's works the carnival turns over the reality, it reflects the general trend of the era. In the 1920s and 1930s, in essence, the semiotic space of culture and the socio-cultural space were transformed. That is why in the literature different semantic codes and images are unexpectedly combined, competing with each other and unexpectedly combined: the city and the village, tradition and innovation, the manual labor and the machine, crowd and elite, the grassroots cultural tradition and the high cultural tradition, art of the past and art of the future, etc. Such a combination is an echo of revolutionary changes in society, it is thesocio-cultural identities re-alignment. Ideology declared the emergence of new type of character the proletarian. Such character'sliterature is depicted by means of humor and satire. This was leading to the emergence of a special type of expression, which, on the one hand, was borrowed from the old forms of folk, a widely popular tradition, and on the other was a topical, avant-garde, experimental thing. And yet the works became widely popular. Ostap Wyshya was called the "king of Ukrainian circulation" (the statement is attributed to the head of the Cultural Department of VURPS T. Babichev). By 1928, the writer had published 23 books, with a total circulation of 400,000 copies, and each year these numbers were increasing. In total, he is the author of 23 books that have survived 42 editions, and the total circulation of Ostap Wyshya's works published before the Second World War exceeds 10 million copies.

The success of the writer's works is due to the fact that he very accurately felt the reader's request: a completely new type of reader - the average, small personality - is coming to the forefront of mass reading and literary life. The everyday life, everyday consciousness and mythology of everyday life can very well be described precisely through a short work, anecdotal history, presented as a humorous case and a smile. Modernity before the eyes of Ostap CherriesWyshya came to life in the small details of everyday life, language, funny situations, language stamps, documents, realities of language and everyday life. They were understandable to his contemporary readers. And they became one of the elements of Ostap Wyshya's poetic world: he transformed stereotypes in culture into a stylistic and ideological component of his texts. Ostap Wyshya's works have many typical for the 1920s-1930s associations, slogans, semantic stereotypical codes, phraseologisms and wellestablished linguistic references, folk expressions, literary reminiscences. The stylistic and ideological play with them has formed the basis of the ridiculous element of Ostap Wyshya's works. 
At the same time, the basis of Ostap Wyshya style is the parody and parody intonation. In some cases, the Ukrainian humorist's parodies the style of thinking (bourgeois, peasant, mass, ideologized) and newspaper reports, conversational speech, in others - real-life stories or the types of personalities that the new socio-cultural reality (pop, proletariat, the proletariat) has brought to life. (employees, writers, etc.).

In addition to parody, another stylistic feature of Ostap Wyshya's creativity is realism. Fact as the basis of a plot or description is a complete component of Ostap Wyshya's works. And these can be different facts. For example, a household, linguistic, or socio-cultural reality: a village club ("We used to have clubs like this in the countryside"), a peasant woman and her life ("Geneva" department), a paper storm of the monthly world news "Missing People"), updating of the icons in Kiev ("Kiev miracles"), walks of burghers in the Proletarian Garden ("Proletarian Garden"), All-Union Agricultural Exhibition (cycle of works of the same name). The writer with his "smiles" compiles a biography of things, everyday scenes, typical personalities, newspaper slogans, era, which proclaimed as his aesthetic reference the change of ideas about culture, way of life, everyday life.

Ostap Wyshya, unlike the radical-minded futurists or proletkultivtsi, who put the fact as a semantic sign, and were reporting a genre over all other artistic realities, sees not only the pathos of building or new country in the facts, but also the dramatic clash of different ideological systems: Russian and Ukrainian, the old pre-revolutionary and the new, militant communist, patriarchal-peasant and industrial. In the everyday existence of the village, city, city suburbs, average servant, little educated peasant and primitive citizen Ostap Wyshya sees the birth of new social system and the rapid transformation of socio-cultural space, when there is a decrease in the general cultural level of the crowd. The multitude that perceives easilythe receptive forms of art and thinking, as well as the offensive of simplistic forms of worldview. This happens when the low culture seeks to replace the high cultural tradition by adapting its semiosphere, recoding its semantic codes and realities.

Overcoming the stamps of mass thinking - one of the leading features of the artistic universe of Ostap Wyshya's humorous prose: introducing his readers to the world of his familiar realities, the writer invites them together to find the boundary that separates true being from vulgar, true art - from inferior, banal one, exquisite language turns - from stereotyped one.

The character of Ostap Wyshya's works is the average man (onedimensional - in Marcurus's interpretation), whom he tries to free by laughter and satire from the mass consciousness embrace. His character is in the mundane chronotype of his world, but he also is captured in a moment of 
strange, paradoxical situation and history. The Ukrainian humorist parodies the plot thinking, destroys the classic storytelling structure to create his own, authorial, genre - a "smile". In this genre, eccentricity of everyday life runs through such dominant semantic-stylistic features as lyricism, which counteracts the ideological, domestic, mental contradictions faced by the average person in real life, and the Wyshya's character in the fictional world. So this is well traced if you look at Ostap Wyshya's work in perspective: the emotional tone of early Wyshya to the period of the second half of the 20th century - melancholy-lyrical, comic noteshas replaced satirical, and plots focused on laughter as a basic form of perception and interpretation of validity. Ostap Wyshya's creativity of the period of cooperation with the VUCSK News is an example of opposition to archaic mass culture, which was widespread in the dark, uneducated village, and at the same time - the desire to promote the formation of new (ironically-lyrical, satirical and dramatic).

\section{The new human in the social realism coordinates}

An example of the history of Ukrainian literature of the 1920s and 1930s shows a change in the pearson's depiction. The basis for this was the aesthetics of mass literature, since the semantic-stylistic codes of mass culture partially coincided with the semiotic codes of social-realist poetics. Which are:

- The literature of social realism combines the features of realism and mass literature. It was characterized by signs of utilitarianism, and its subjects had to be conformed to the ideology. The works of mass and socialist literature clearly trace the ideological choice of values, models that will give the expected effect - either the interest of the mass audience or the approval of the authorities, but in general its purpose is to extend the concept of one-dimensional behavior in the individual.

- Absolutization of universal semantic codes. Gender, social, cultural, mental, national stereotypes are absolutized in the mass literature. In the literature of socialist realism, ideological stereotypes are absolutized. The established images of social-realist literature are addressed to the mass readership. They are clear to the readers, easily perceived on the basis of other semantic codes, signs, symbols, commonly known themes, motives, story schemes. This approach made it possible to combine a large number of readers around clearly defined topics and subjects. The mythological hero was addressed only fom this audience. It is a perfect character, with perfect traits and deeds.

- Focus on the collective perception and upbringing of the reader. Such a reader had to dedicate himself to the character, to the typical situations in 
which the character gets. The story for such a reader is based on the principles of clear genre canons, stories, style, it has a happy ending, it is optimistic and pathetic. Mass literature and social realism are based on the principles of rhetorical poetics, where the elevated pictures of heroes are unfolded consistently, objectively, it must coincide with the same elevated, optimistic images of social reality. Futhermore, in culture and literature, the impression of the one-dimensional reality is equally pathetic in real life and in artistic creation.

- Dual identification of the character and the reader. On the one hand, the reader must form those traits that are inherent in the mythologized character's traits, on the other - the character in the text is a universal image that has traits, behavior, feelings, which is inherent to all people in general. Such a character - is a kind of archetype in literature, his nature is a set of total emblematic features.

- The way stories are told and the genres chosen by social realism are based on the principles of repetitiveness, fixed schemas, which is inherent in the poetics of mass literature. Social realism invited the reader to the world of well-known ideas and plot schemes, familiarized with well-known images and compositional techniques. This brought the poetics of two different semiotic systems closer together - mass literature and social-realist literature.

The tragedy for Ukrainian literature of the 1920s and 1930s was the violent cessation of the search for the formation of a nationally conscious mass audience and a nationally conscious elite, trying to appeal to the mediocre and standardized taste of the Soviet elite and the Soviet nation. Nation in this context is not synonymous with national, instead it is analogous to crowd, widespread. Gradually, the images of the reflexingcharacter, the ironic character disappears from the literature, and the mythological hero becomes widespread, supported by the official literary canon.

At the forefront of history came not a unique personality, nor the type of the new era, but the type of person from the crowd, integral monolithic formation (with common ideological settings, aesthetic tastes, ideological beliefs, social origin, etc.). A different system of relations between the literary text and the reader, between the writer and the reader was formed, as well as a different type of perception of the artistic text, based on a rigid system of criteria and norms. Geo Kolyada in the Etudes for 1928 figuratively described the literary situation of the day: "Here are the topics: gang, love, turmeric, bourgeois, red, black, communist and only clothing, brand and verbal adultery. And where is the human? It's gone. It was driven into a swamp, flooded, and a leather jacket or scroll was put on her corpse, 
with the cylinder on it -that's all. Here is a human for you!"23. Such personalities became the new class of the new society and, at the same time,they became the characters of artworks, and creators of new literature, and its critics. The new reader stood guard not only for the new power, but also for the ideas and art forms that prevailed in literature.

The 1920s-1930s is a period in Ukrainian literature of literary space formation, in which the social and ideological concepts are proclaimed above the aesthetic perfection of a work of art. The hero of this era were the character described by G. Kolyada - with a social but not spiritual biography. The idea of creativity should have been combined with the social idea created by the crowd. And the socio-political factor in this process played a more important role than the aesthetic criteria. On the pages of the magazines "The Red Road", "Life and Revolution", "Socialist Culture" and others the idea of a new person was spreading. It was not a reflective person, but a person with a perfect social biography and perfect ideological views. The reading was interpreted not so much as an aesthetic experience, but as a socio-informational, cognitive one, and the range of interpretations of the artistic text was limited by ideologists, aesthetic requests of the new social strata - the proletariat.

M. Skrypnyk describes the prospects for the development of Ukrainian literature in the book "Literature and Art in the 1930s": "To identify the pathos of socialist creativity in the reconstruction of the country, to find ways, images and forms in accordance with those majestic processes involving millions - this is a challenge for our literature" ${ }^{24}$. Ideologists saw the main task of literature and culture as to create a new character in literature and to introduce it to a new reader. So then, M. Skrypnyk wrote that this new literature was "designed for the true mass reader, the working class and the peasant; we must boldly and resolutely break the prejudices of the parish in literature, and, by using all the technical advances of old craftsmanship, produce a form that is understandable to millions. Only then will Soviet literature and its future proletarian avant-garde be able to fulfill their cultural mission as they accomplish this great task" 25 . "A new person a new character - a new literature" - this was the way ideologists developed in the literature and culture in the 1920s and 1930s.

Socialist literature tries to describe all new layers of society. Thus, playwright Ivan Mykytenko wrote: "The subject matter of our literature is enormous, majestic, and I must say that we have not overlooked any topic in

\footnotetext{
${ }^{23}$ Коляда Гео. Етюди. Нова генерація. 1928. № 10. С. 236.

${ }^{24}$ Скрипник М. Література й мистецтво. Статті й промови. Т. V. Х.: Держвидав України, 1930. С. 75-76.

${ }^{25}$ Ibid., c. 264.
} 
our work. We have touched upon all topics - both about industrialization, and mechanization, and about collectivization, and about re-educating man, and about creating a new man" ${ }^{26}$. The wide range of topics in Ukrainian literature is a result of socio-cultural factors: the new character seemed to "tell" the reader what he should be like in modern times, how he should behave, what words to say, what actions to take.

\section{CONCLUSIONS}

Three models of portrayal of a new person in Ukrainian literature of the 1920 s and 1930s testify to the similarity and difference in the creative practices of writers of the period. In all three models, writers use the same rhetorical stamps and stereotypes, which are ideologically labeled. But careful study and comparison of contexts reveals that this conceals different styles and genres.

Yes, a social person has the traits of a mythological character, a hero whomakes achievements, subordinates his life to ideology, social circumstances. Such a character is described, for example, in the plays of Ivan Mykytenko. Its main features are devotion to ideology, positive character traits, lack of doubt, experiences. Works that describe such a character are pathetic and ideologically labeled. This is the perfect character to appear in Soviet cinema, on Soviet posters, propaganda. It combines the ideology and stereotypes of mass culture. A special place among the new semantic codes upon which all Soviet literature and culture, including mass ones, will be based is positive pathos. Meeting the leading expectations of the mass audience, culture and literature are guided by the idea of ordering chaos and the utopian idea of the arrival of a new bright future.

Another type of character is a Faustian man. He constantly hesitates, experiences various doubts, reflexes, is disappointed in the revolution, is experiencing an existential crisis. This character is described by Nikolai Khvylovy. The writer considers this character a true type of era. The author portrays such a person in a moment of dramatic crisis. Therefore, for such a person in the works of Mykola Khvylovy are characterized by traits of confusion and a split consciousness. Such a character clearly describes the contradiction between the conscious and the subconscious, ideology and humanity, believe in the future renewal and disappointment in the ideals of the revolution.

An example of the ironic portrayal of a new person is Ostap Wyshya's works. His "smiles" are an original genre in Ukrainian literature. In them,

\footnotetext{
${ }^{26}$ Микитенко І. К. Твори: в 4 т. Т. 4. П'єси; публіцистика; Про себе і свою творчість; Листи. Упоряд. О. Микитенко. К.: Дніпро, 1983. С. 261.
} 
the writer portrays a typical person who is going through an era of change. The villagers or laborer, resident of a town or small village in Ostap Wyshya becomes the character of a satirical or ironic story. The writer described a huge number of typical scenes of the era. They were not just the order of the editorial staff in which Ostap Wyshya worked, but a kind of social order for a wide variety of readers. Thanks to the "smiles" of OstapWyshyahave semantized (acquired names, definitions, described, classified, etc.) a variety of manifestations of reality, not yet classified by sociologists, ideologists, politicians, or even prose writers, journalists. He was the first - acutely, sensitively, ironically - to describe a new society, a new mass social stratum, from which the communist power would then form a socio-cultural integrity - the Soviet people. The irony of Wyshya, the powerful force of his criticalsatirical word, led to the gradual formation of an ironically dual attitude toward Soviet reality (in the form of anecdotes, mockery of socio-cultural and ideological semantic codes).

These three types of characters in Ukrainian literature of the 1920s and 1930s testify to the existence of three models of human image at this time. The first is based on the myth of a new ideology-oriented hero. The second is based on the writers' desire to portray the bewilderment and disappointment of a young man in an era of revolutionary change. The third is based on the idea of an ironic and satirical portrayal of a small man in times of revolutionary transformations. Subsequently, only the first will become entrenched in Ukrainian literature and become an example of a combination of ideology and mass culture and literature.

\section{SUMMARY}

This study seeks to systematize and summarize three models of the image of a new person in Ukrainian literature of the 1920s and 1930s. Ideas for semiotics and the link between sociocultural change and the change in character type in literature have been the intellectual support of this research. This made it possible to describe three types of characters in Ukrainian literature of the 1920s and 1930s. The first is a mythological hero who faithfully serves ideology, ready to perform for its own sake. This type of character will spread not only in literature, but throughout the culture of the Soviet Union. The second type of character is the Faustian man. This is a character who is dramatically frustrated with the ideas and ideals of the revolution, who does not believe in social change and finds itself on the sidelines of life. Writers, in order to portray such a character, resort to artistic techniques of impressionism, realism, expressionism. The third type of character is an ironic character. It is a small man depicted by means of irony, satire, allegories in the original genre of Ukrainian literature - a smile. 


\section{REFERENCES}

1. Вишня Остап. Твори в 5 т. Т. 2. Усмішки, фейлетони, гуморески. К. : Дніпро, 1974. 358 с.

2. Доленго М. Післяжовтнева українська. Червоний шлях. 1927. № 11. С. 154-172.

3. Івченко М. Записники. 1915-1933 роки. Відділ рукописів ін-ту лі-тератури ім. Т.Г. Шевченка. Ф. 109. № 89-93.

4. Кавун Л. І. “М'ятежні” романтики вітаїзму: проза Вапліте. Черкаси : Брама-Україна, 2006. 328 с.

5. Коваленко Б. Пролетарські письменники. Х.-К. : Державне видво “Література і мистецтво", 1931.48 с.

6. Коляда Гео. Етюди. Нова генераиія. 1928. № 10. С. 236-237.

7. Коряк В. В боях: Статті і виступи 1925-1930. Х. : Література і мистецтво, 1933. $396 \mathrm{c.}$

8. Левченко О. Г. Текст культури в пошуках автора: Масова свідомість і художня культура у контексті радянської культури (за матеріалами театру і кіно). Держ. центр театр. мистец. ім. Леся Курбаса. К., 2006. 300 с.

9. Лотман Ю. М. Семиосфера. СПб : “Искусство-СПБ”, 2010. 704 с.

10. Микитенко І. К. Твори: в 4 т. Т. 3. П'єси. Упоряд. О. І. Микитенко. К. : Дніпро, 1983. 479 с.

11. Микитенко I. Пролетарська література за доби реконструкції (Доповідь на другому з’їзді ВУСП (звіт секрет.). Гарт. 1929. № 9. С. $111-173$.

12. Микитенко I. К. Твори: в 4 т. Т. 4. П’єси; публіцистика; Про себе і свою творчість; Листи. Упоряд. О. Микитенко. К. : Дніпро, $1983.558 \mathrm{c}$.

13. Репресоване "Відродження". Упоряд. О. І. Сидоренко, Д. В. Табачник. К. : Україна, 1993. 399 с.

14. Сихно-Хоменко I. Пролетарська література. Життя і революція. 1929. № 12. С. 18-24.

15. Скрипник М. Література й мистецтво. Статті й промови. T. V. Х. : Держвидав України, 1930. 300 с.

16. Філатова О. С. Український роман $20-30-\mathrm{x}$ років XX століття: типологія авторської свідомості. К. : Київ. нац. ун-Т ім. Т. Шевченка. Миколаїв : Іліон, 2010. 484 с.

17. Хархун В. П. Соцреалістичний канон в українській літературі: генеза, розвиток, модифікації. Ніжин : Гідромакс, 2009. 508 с.

18. Хвильовий М. Г. Вибрані твори. Упоряд. Ростислав Мельників. К. : Смолоскип, 2011. 1035 с.

19. Хвильовий М. Твори в 2-х т. Т. 1-2. К. : Дніпро, 1990. 650 с. 
20. Якубський Б. Життя молоде (Спроба літературної характеристики “київських плужан”). Червонийшлях. 1925. № 9. C. $159-171$.

Information about the author: Romanenko O. V., Doctor of Philology, Associate Professor at the Institute of Philology, Taras Shevchenko National University of Kyiv 64/13, Volodymyrska str., Kyiv, 01601, Ukraine 